Article

\title{
Garnet-Rich Veins in an Ultrabasic Amphibolite from NE Sardinia, Italy: An Example of Vein Mineralogical Re-Equilibration during the Exhumation of a Granulite Terrane
}

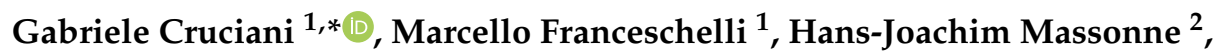 \\ Giovanni Musumeci ${ }^{3}$ and Massimo Scodina ${ }^{1}$ \\ 1 Dipartimento di Scienze Chimiche e Geologiche, Università di Cagliari-S.S. 554 Cittadella Universitaria, \\ 09042 Monserrato (CA), Italy; francmar@unica.it (M.F.); mskodo85@tiscali.it (M.S.) \\ 2 School of Earth Sciences, China University of Geosciences, Lumo Road 388, Wuhan 430074, China; \\ h-j.massonne@mineralogie.uni-stuttgart.de \\ 3 Dipartimento di Scienze della Terra, Università di Pisa, Via S. Maria 53, 56126 Pisa, Italy; gm@dst.unipi.it \\ * Correspondence: gcrucian@unica.it; Tel.: +39-070-6757709
}

Received: 30 July 2020; Accepted: 28 August 2020; Published: 31 August 2020

check for updates

\begin{abstract}
A complex system of mono- and polymineralic centimeter-thick veins occurs within the ultrabasic amphibolites of Montigiu Nieddu hill in northeastern Sardinia, and they are filled with garnet, amphibole, chlorite, and epidote. Some garnet-rich veins are margined by an amphibole layer at the interface with the host rock and/or show replacement of epidote concentrated in the vein core. Together with homogeneous matrix garnet (Grt1), millimetric, euhedral, and strongly zoned garnet porphyroblasts occur within these veins. The estimated pressure-temperature conditions $\left(\mathrm{P}=1.0-1.7 \mathrm{GPa}, \mathrm{T}=650-750{ }^{\circ} \mathrm{C}\right)$ for the formation of Grt1 match the metamorphic peak and early exhumation derived previously for the host rocks and confirm that the garnet veins also formed under high-pressure (HP) conditions. The igneous protolith of the host rocks experienced HP metamorphism in a subduction zone and underwent exhumation in an exhumation channel. The vein system in the ultrabasic amphibolites formed by cyclic hydrofracturing as rapid and transient events such as crack-seal veining. The growth of multiple vein-filling mineral assemblages indicates the formation of separate vein-producing cycles.
\end{abstract}

Keywords: ultrabasic amphibolite; metamorphic vein system; P-T evolution; Variscan Sardinia

\section{Introduction}

Progressive changes in deformation style and pressure-temperature conditions during prograde and retrograde metamorphism influence the style, scale, and distribution of fractures and veins in metamorphic terranes. Throughout each metamorphic event, such fractures are filled with a sequence of mineral phases that testifies to the presence of fluids and their flow and reactions with the host rock [1]. Along the NE coast of Sardinia, within the Migmatite Complex of the Golfo Aranci area, in the Inner Zone of the Variscan Sardinian belt, ultrabasic amphibolites crop out at the top of Montigiu Nieddu hill (Mt. Nieddu). These rocks are crosscut by a complex system of mono- and polymineralic veins developed in response to ductile to brittle deformation. This system comprises garnet veins, as well as clinozoisite and amphibole veins, recording several events of fracturing and crystallization likely associated with fluid-rock interaction and/or metasomatism. The vein-system evolution accompanied the metamorphic history of the host rocks, which is related to continent-continent collision in one of the best-preserved branches of the southern Variscan belt. 
Some studies are available in the literature focusing on metamorphic vein systems [2,3], but only a few of them deal with veining in metabasic [4] to ultrabasic rocks [5]. The purpose of this work is (i) to present a geological, petrological, and geothermobarometric investigation of the vein system recognized in the ultrabasic amphibolites in the Golfo Aranci area; (ii) to constrain the vein-forming processes and the pressure-temperature (P-T) conditions of veining; and (iii) to link them to the evolution of the host rock with reference to exhumation processes in subduction zones related to collisional orogens. We demonstrate that the vein system developed through different steps during the exhumation of the ultrabasic amphibolites in the course of the continental collision between Laurussia and Gondwana.

\section{Geological Setting}

The Sardinian basement is part of the Corsica-Sardinia microplate, a segment of the Southern European Variscan belt. This basement is made up of metaigneous to metasedimentary sequences, ranging in age from Cambrian to Lower Carboniferous, and was affected by Devonian to Carboniferous deformation due to the collision between the Gondwana, Armorica, and Laurussia continental plates [6,7]. This basement has been subdivided into three main tectono-metamorphic zones, with the metamorphic grade increasing from the southern External Zone (foreland zone in the inset of Figure 1), to the central Nappe Zone and Inner Zone in the northernmost part of the island [7]. In the External and in the Nappe Zones, the Palaeozoic rocks consist of metasedimentary sequences with metavolcanics that were emplaced during the Late Ordovician [8-10]. The high-grade metamorphics of the Inner Zone continue to southern Corsica [11]. The Inner Zone is further subdivided into a southern Low to Medium-Grade Metamorphic Complex (L-MGMC) and a High-Grade Metamorphic Complex (HGMC). The HGMC mainly consists of multideformed sedimentary-derived gneisses and high-pressure (HP, 1.3 GPa) migmatites [12-15], belonging to the sillimanite + K-feldspar zone. Within the HGMC, metamorphosed Ordovician granites (now orthogneisses), calc-silicate nodules, and metabasite lenses (basic and ultrabasic rocks with eclogite and granulite facies relics [16-20]) also occur. The southern L-MGMC is made up of micaschists and paragneisses locally with relics of HP assemblages [21] and with sporadic quartzite and metabasite bodies [22-24]. The Inner Zone of northern Sardinia underwent a polyphase ductile deformation $[25,26]$. The oldest deformation phase (D1), dated to $345-340 \mathrm{Ma}$ by [27] and [28], is well preserved in some areas of the L-MGMC [21], and it has been referred to the collisional stage [6].

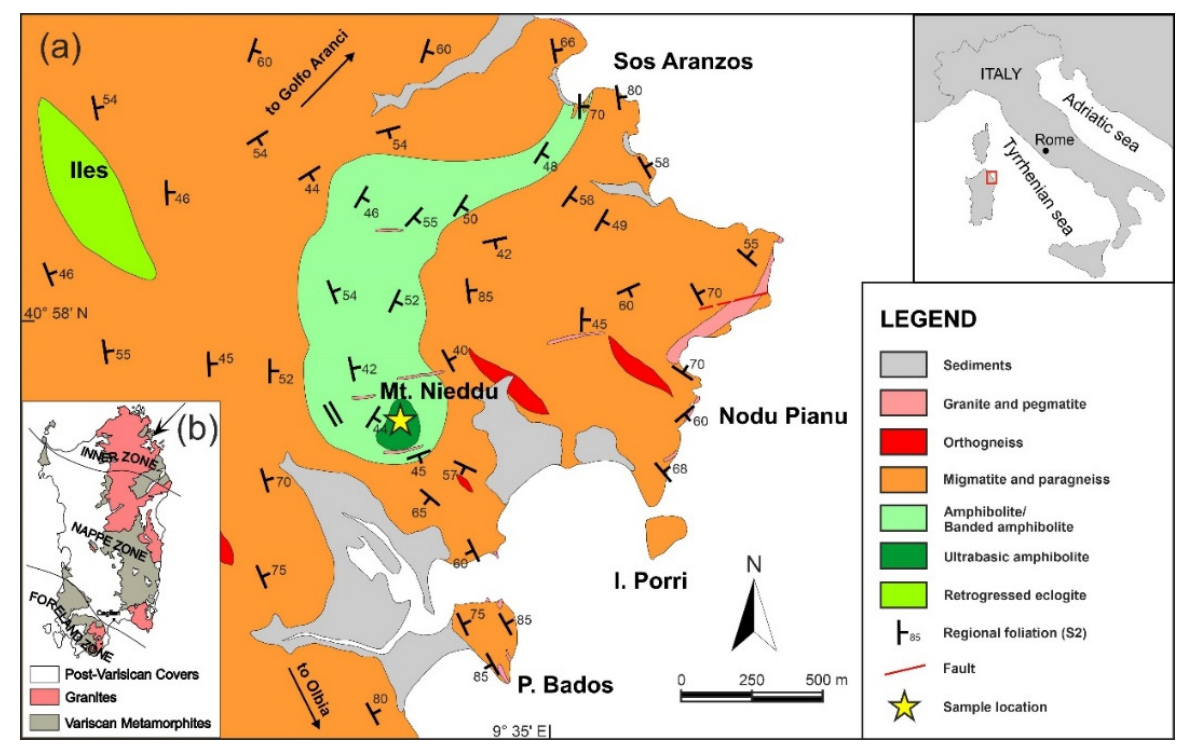

Figure 1. (a) Geological sketch map of the Mt. Nieddu area, (b) Tectonic sketch map of the Sardinian Variscan chain. 
The D1 deformation in the HGMC, not clearly discernible in the field, is sporadically documented by the transposition of centimeter-sized leucosomes in the migmatites. The D2 deformation phase is related to the development of NE verging folds and dextral shear zones in the field. The widest D2-related shear belt marks the boundary between the L-MGMC and the HGMC. In the HGMC, N140 ${ }^{\circ}$-striking isoclinal folds with a SE dip of $2-18^{\circ}$ are related to the D2 deformation. Two opposite senses of shear (top-to-NW and top-to-SE/NE) on the S2 foliation are associated with the end of compression/crustal thickening (the first, top to NW) and with tectonic inversion during the exhumation of the metamorphic basement (top-to-SE/NE) [29]. D3 folds are associated with an S3 axial plane crenulation cleavage. The D4 tectonic phase is revealed by metric to decametric folds with sub-horizontal axial planes. The metamorphic basement of Sardinia was finally intruded by melts of the Permo-Carboniferous batholith emplaced between $\sim 340$ and $280 \mathrm{Ma}$ [7,27,30,31]. Carboniferous-Permian sedimentary basins [32] and Permian volcanics cover the crystalline basement.

\section{Field Geology and Petrography}

The study area is located in the northeastern part of Sardinia, which geologically belongs to the HGMC. The studied rocks are exposed a few kilometers NE of the town of Olbia (at Mt. Nieddu, Figure 1) near Golfo Aranci, where a large lens-shaped amphibolite body, $1.5 \mathrm{~km}$ long in NE-SW direction and $500 \mathrm{~m}$ wide, crops out. Two main lithologies are distinguished in this metabasite body: amphibolite/banded amphibolite and ultrabasic amphibolite [33]. The banded amphibolites are massive to poorly foliated rocks, mainly consisting of amphibole, plagioclase, quartz, garnet, and rare pyroxene. They show an alternation of dark, amphibole-rich and whitish, plagioclase-rich layers, best recognizable in the outer part of the Mt. Nieddu metabasite lens (Figure 1). The dark and whitish layers are parallel to the main regional schistosity (S2). The ultrabasic amphibolites described below are the host rock of the here-investigated vein system. The migmatites, hosting the metabasite lens, are coarse-grained rocks with stromatic fabric and a well-developed foliation and can be derived from an original psammitic to pelitic sedimentary sequence. All the metamorphic rock types in the study area are crosscut by discordant meter-sized dykes of leucogranitic composition.

\subsection{Ultrabasic Amphibolite}

Enclosed within the banded amphibolite, a small body of dark green to black ultrabasic amphibolite occurs, in which granulite facies relics have been recorded $[34,35]$. The contact between the ultrabasic amphibolite and the banded amphibolite, striking $\mathrm{N} 40^{\circ}$ and dipping SE $45^{\circ}$, is sharp. In spite of a strong re-equilibration under amphibolite facies conditions, the ultrabasic amphibolites preserved relics of igneous minerals along with metamorphic phases. On the basis of the mineral content and distribution, three main compositional layers of the ultrabasic amphibolite have been distinguished (layers A, B, and C, [34,35]). All three layers are inhomogeneous in mineralogical composition, with variable size and shape of the main rock-forming minerals.

The dark-grey to reddish Layer A is about $20 \mathrm{~m}$ thick. It is characterized by the occurrence of igneous olivine grains, locally surrounded by a discontinuous thin layer of orthopyroxene. Igneous orthopyroxene, amphibole, chlorite, and green spinel, forming worm-like microstructures and patches in association with amphibole or around garnet, also occur. Minor garnet and plagioclase are also present. Chlorite occurs in small veins, which can contain late stage amphibole.

Layer B is around $5 \mathrm{~m}$ thick, lenticular, and dark grey to greenish in color and consists mainly of greenish amphibole and coarse-grained plagioclase crystals (up to $1 \mathrm{~cm}$ in length). Coronitic textures are characterized by layers of orthopyroxene and clinopyroxene around olivine, and by a symplectite of clinopyroxene + spinel and garnet coronas around plagioclase; igneous mineral relics and coronitic minerals were overgrown by amphibole.

Layer C, exposed at the top of Mt. Nieddu, is a dark-green, garnet-rich amphibolite. It is characterized by the occurrence of porphyroblastic garnet and large amphibole grains (up to $4-5 \mathrm{~cm}$ ), together with spinel, plagioclase, pyroxene, and chlorite. Epidote replaced garnet locally. Layer C is 
featured by the occurrence of garnet nodules made up of garnet, amphibole, spinel, and large amounts of epidote. These nodules, ranging in size from 1 to $15 \mathrm{~cm}$, are ellipsoidal in shape and commonly are either surrounded by a 1-2 mm thick amphibole-rich rim or crosscut by amphibole-rich veins. Further details on the field aspect, petrography, and petrological significance of this layer can be found in [35].

\subsection{Vein System}

The ultrabasic amphibolites are characterized by the widespread occurrence of lenticular-to-tabular-shaped mono- and polymineralic veins, centimetric in width and decametric-to-metric in length. Garnet-rich veins occur in layers A and C and show variable width $(1-5 \mathrm{~cm})$ and NE-SW-striking orientation with variable dip. Small sets of parallel veins (Figure 2a) display a blocky texture of garnet crystals, commonly associated with amphibole and spinel at the vein edges. Garnet-rich veins are often surrounded by a reaction zone of amphibole up to 1-2 cm in width (Figure 2b). Epidote locally replaced garnet in the vein core or, less frequently, in the whole vein (Figure 2c). The core of these garnet-rich veins is locally characterized by a large epidote-dominant area (Figure 2d), in which several millimetric, euhedral, and zoned garnet porphyroblasts occur (Figure 3).

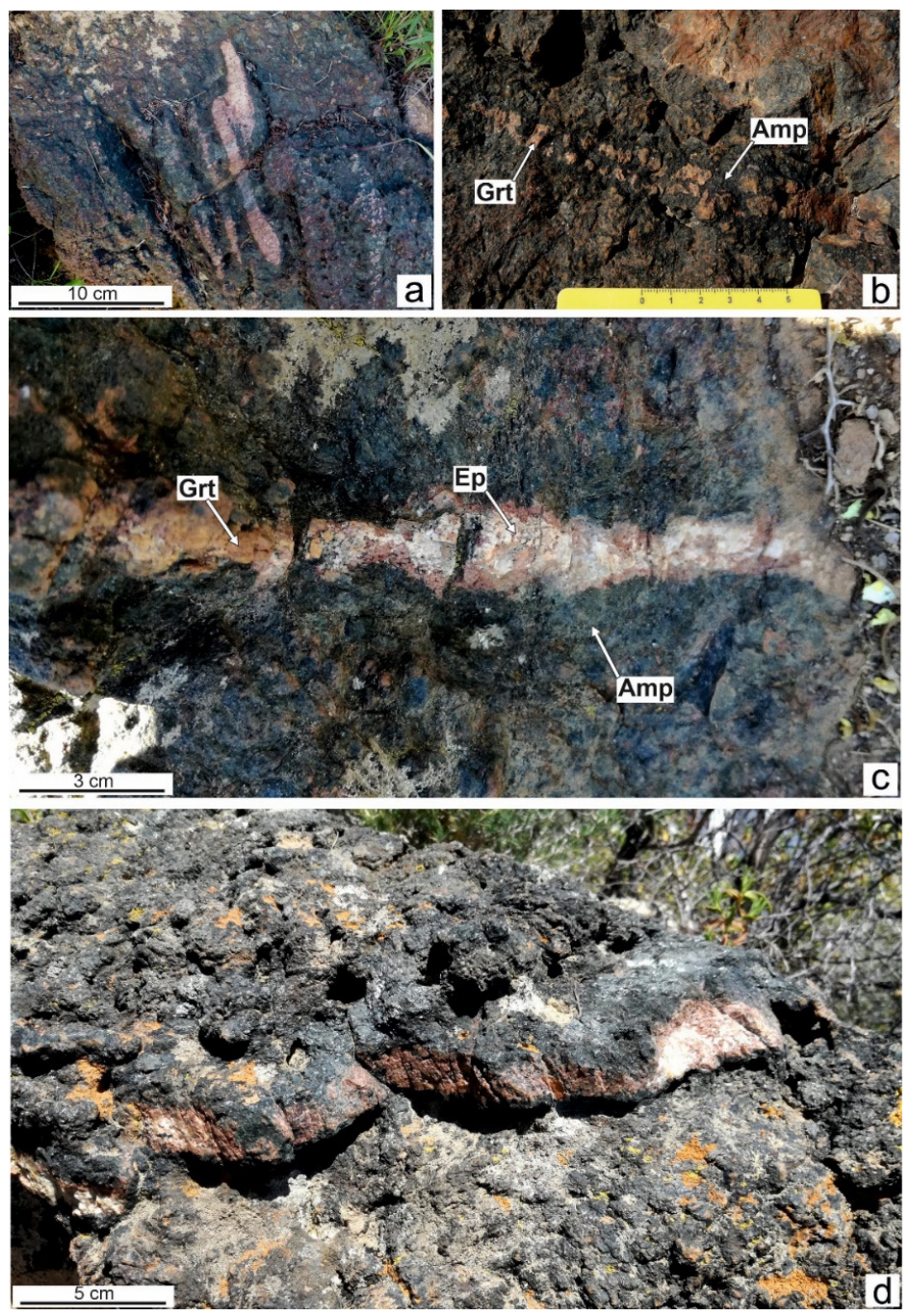

Figure 2. Field photographs of different garnet veins in Layer $\mathrm{C}$ of ultrabasic amphibolites from Golfo Aranci area: (a) Decimeter-sized garnet veins subparallel to S2; sample MN50; (b) Garnet vein with amphibole rim; (c) Garnet vein with epidote in its central part, surrounded by an amphibole rim; from the wall-rock to the vein center, a clear, symmetric mineralogical sequence is observed; (d) Garnet-rich vein near to the top of Mt. Nieddu with epidote; sample MN21V. Grt = garnet; Amp = amphibole; Ep = epidote. 


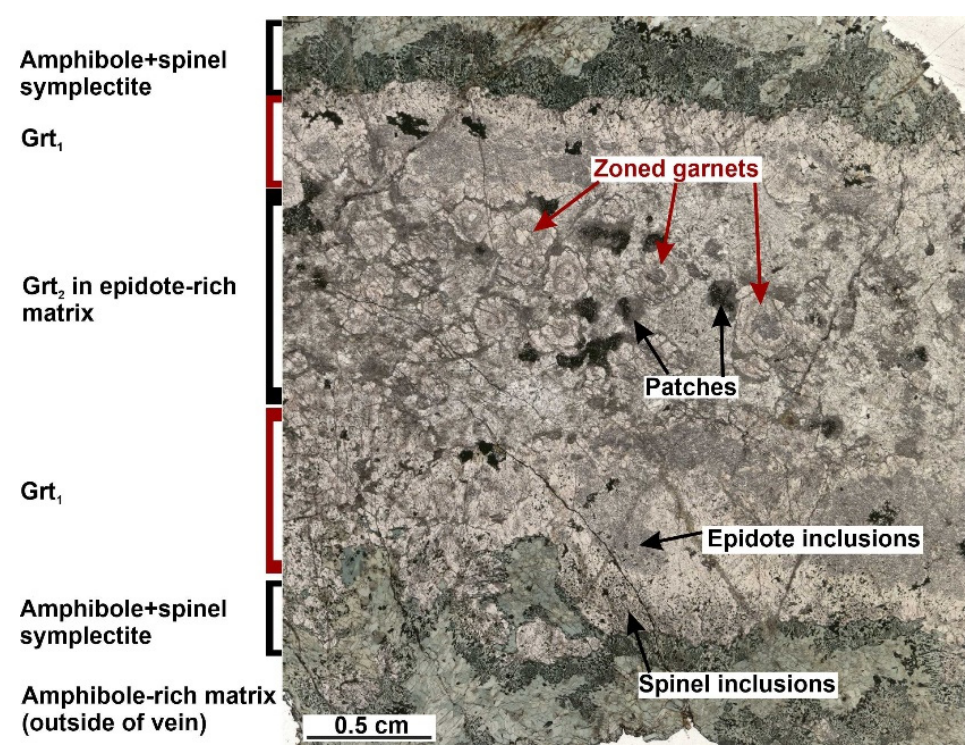

Figure 3. Photo-scan of a thin section of the garnet-rich vein shown in Figure 2d (sample MN21V).

Amphibole-rich veins occur as thin layers (centimetric in width) of dark-green-to-black, medium-grained crystals, crosscutting all the aforementioned rock layers. Amphibole veins commonly show garnet relics, or more rarely olivine, in the vein center. Amphibole veins with no visible relics (to the naked eye) are very rare; these veins show a medium-to coarse-grained size and can display different textures, from fibrous to blocky, with a prevalent elongated blocky texture growing in an apparent syntaxial morphology.

Chlorite-rich veins are hardly recognizable in the field due to their very small dimensions (up to $1-2 \mathrm{~cm}$ in width) and their dark-grey color similar to that of the host rock. They show a fibrous texture with randomly oriented (but generally parallel to the vein direction) lamellar crystals. These veins only occur in the olivine-bearing Layer A.

Epidote-rich veins occur mostly in the garnet-rich compositional layer but are also visible in the rocks of Layer A. They show variable width (from millimetric to $3 \mathrm{~cm}$ ), length (decimetric), and orientation. These veins are whitish with a blocky texture and commonly show the replacement of minerals, mostly garnet and rarely amphibole, by epidote. Locally, epidote (core of the vein) and garnet (rim) occur in the same vein. Such veins can also preserve relics of amphibole. Epidote-rich veins can occur also as millimetric-to-sub-millimetric fillings of late fractures.

\section{Materials and Methods}

Microstructural studies of selected samples of the veins were performed with a FEI Quanta 200 scanning electron microscope equipped with a ThermoFisher EDS microanalyzer at Centro Servizi di Ateneo per la Ricerca (CeSAR), Università di Cagliari. For these studies, carbon-coated polished thin-sections were used. The chemical compositions of the vein minerals were determined with a CAMECA SX100 electron microprobe (EMP) equipped with five wave-length dispersive (WD) spectrometers at the Institut für Mineralogie und Kristallchemie (IMK, closed), Universität Stuttgart. The operative conditions included $15 \mathrm{kV}$ acceleration voltage, 15 (garnet) or $10 \mathrm{nA}$ (other silicates) beam current, and $5 \mu \mathrm{m}$ spot size. For the description of the used standards, counting times, and analytical errors see [36]. The structural formulae of the rock-forming minerals were calculated using the CalcMin program [37]. 


\section{Garnet-Rich Veins: Microfabrics and Mineral Chemistry}

\subsection{Microfabrics}

The garnet-rich veins appear as pinkish, centimeter-thick $(1-5 \mathrm{~cm})$ polymineralic veins, rarely completely filled only by garnet. They are usually characterized by a well-defined structure from wall-rock to center (Figure 3). The vein/wall rock boundary is defined by an irregular symplectite-like microstructure made up of late spinel ( $\left.\mathrm{Spl}_{2}\right)$ and amphibole (Amp) that is up to $2 \mathrm{~mm}$ thick (Figures 3 and $4 \mathrm{a})$. The vein edge is made up of a coat of garnet $\left(\mathrm{Grt}_{1}\right)$. This coat is up to $2 \mathrm{~mm}$ thick and contains several inclusions of early spinel $\left(\mathrm{Spl}_{1}\right)$, and minor chlorite $(\mathrm{Chl})$ and corundum (Crn). Close to the vein/host rock interface, rare clinopyroxene occurs, which is commonly too small to be analyzed because the original grains were widely replaced by late amphibole. As we approach the center of the vein, epidote inclusions also occur $\left(\mathrm{Ep}_{1}\right.$; Figure $\left.4 \mathrm{a}\right)$, whereas $\mathrm{Spl}_{1}$ inclusions tend to disappear. Despite this observation, spinel and epidote can be locally found in association along the garnet coat, which, in turn, is characterized by a slight patchy zoning (Figure $4 b$ ).
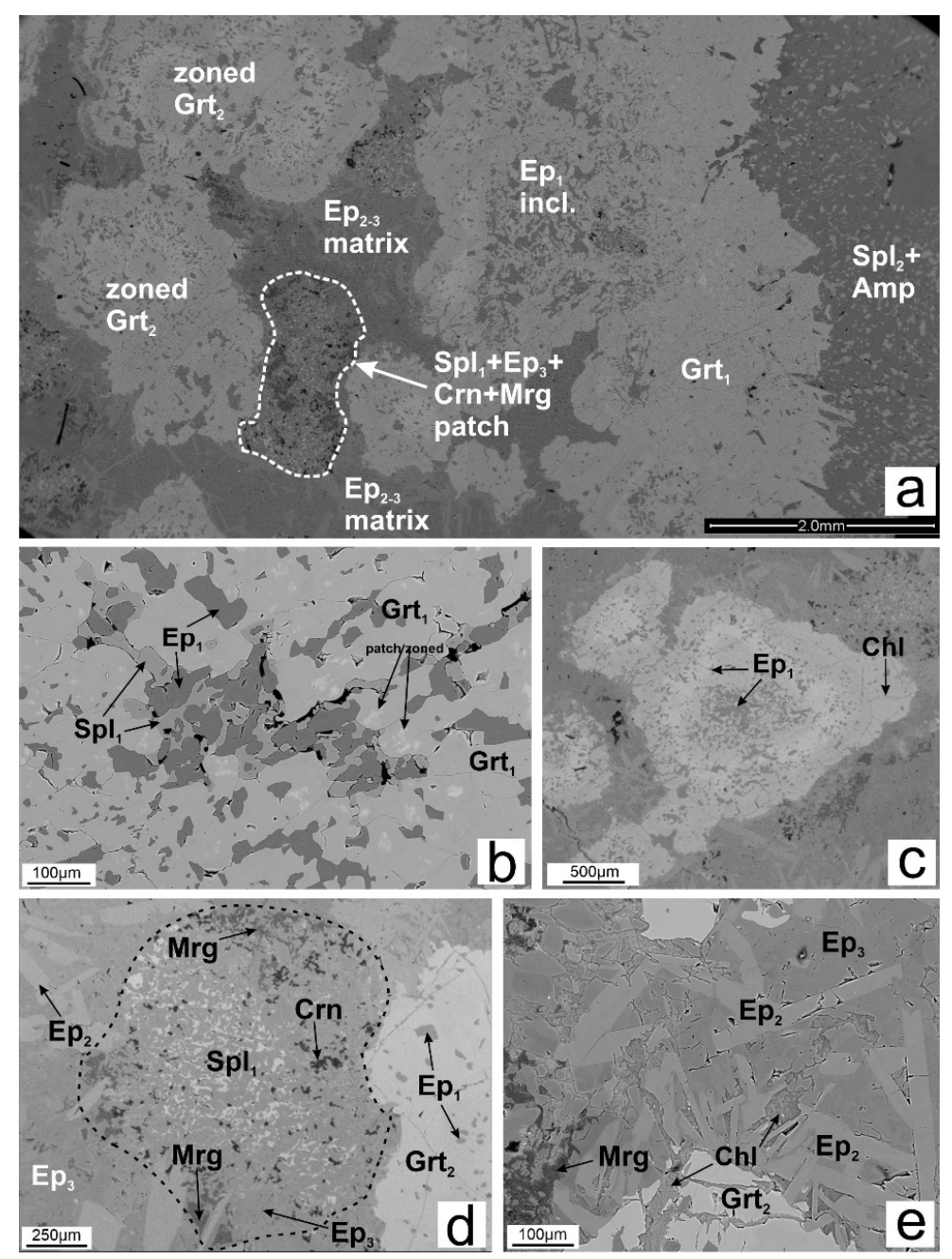

Figure 4. Back-scattered electron (BSE) images of the most relevant microstructures of garnet-rich veins (composite) from ultrabasic amphibolites of Mt. Nieddu: (a) General overview of a garnet vein section from core (left side of the photo) to rim (right side of the photo); (b) Detail of an association between epidote and spinel in the garnet coat (Grt1); (c) Overview of a zoned garnet porphyroblast inside the core of the vein; it contains several epidote inclusions; (d) Detail of a sub-rounded patch in the epidote matrix; (e) Detail of the epidote matrix. Grt = garnet; Spl = Spinel; Amp = amphibole; Ep = epidote; $\mathrm{Crn}=$ corundum; $\mathrm{Mrg}=$ margarite; $\mathrm{Chl}=$ chlorite . 
The sub-rounded shape of the patches (Figures 3 and 4d) suggests the replacement of a pre-existing mineral. These patches are made up of evenly distributed groundmass epidote $\left(\mathrm{Ep}_{3}\right)$, spinel $\left(\mathrm{Spl}_{1}\right)$, margarite (Mrg) and Crn. Mrg and Crn are usually found close to the edge, whereas $\mathrm{Spl}_{1}$ occurs in the core.

The inner portion of the vein consists of several zoned garnet porphyroblasts (Grt 2 , Figure $4 \mathrm{a}, \mathrm{c}$ ) and sub-elliptical spinel + epidote + corundum + margarite patches (Figure $4 \mathrm{~d}$ ) surrounded by an epidote-rich matrix (Figure $4 \mathrm{e}$ ). The Grt 2 grains are up to 3-4 $\mathrm{mm}$ in diameter; they show a noticeable compositional zoning under both optical and electron microscopy (Figure 5, see next section). These crystals are euhedral to subhedral and show several epidote inclusions (Ep 1 ) with minor Chl, which appears as small veins, filling cracks (Figure $4 \mathrm{c}$ ) or along the rim.
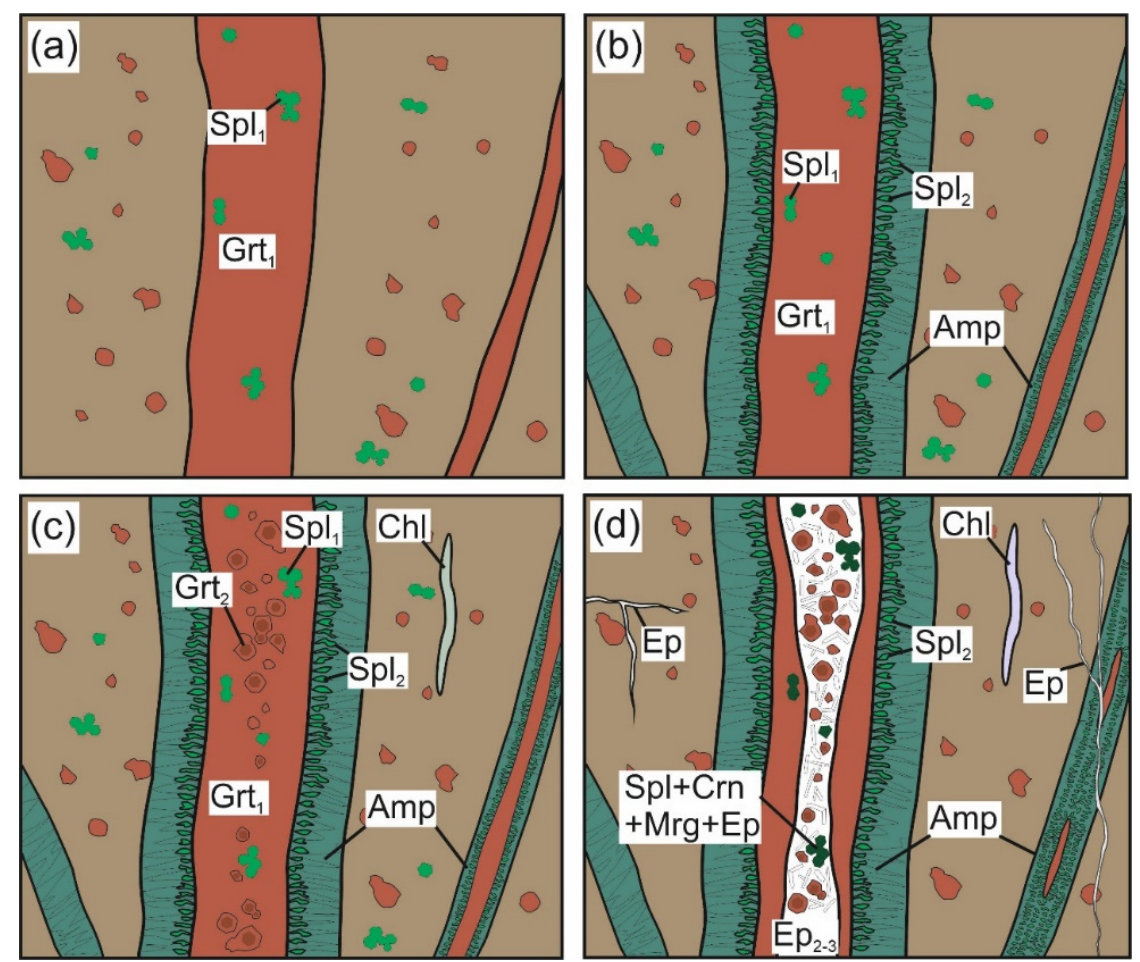

Figure 5. Evolution sketch of the vein system in ultrabasic amphibolites of Mt. Nieddu. (a) First stage, garnet vein formation; (b), (c) Second stage, amphibole formation and growth of compositionally zoned garnet crystals; (d) Third stage, epidote formation. Grt = garnet; Spl = Spinel; Amp = amphibole; Ep = epidote; $\mathrm{Chl}=$ chlorite; $\mathrm{Mrg}=$ margarite; $\mathrm{Crn}=$ corundum .

The epidote matrix (Figure 4a,e) surrounding $\mathrm{Grt}_{2}$ and the abovementioned patches are made of two epidote types: elongated euhedral crystals $\left(\mathrm{Ep}_{2}\right)$ and $\mathrm{Ep}_{3} . \mathrm{Ep}_{2}$ crystals show an isotropic orientation. $\mathrm{Ep}_{3}$ is characterized by patch-zoning (Figure 4e). Chl also occurs in these microdomains. A sketch of the vein system evolution, inferred from the described microfabrics, is illustrated in Figure 5. This evolution can be summarized in the following three stages:

Stage I refers to the development of Grt $_{1}$ veins (Figure 5a), before the development of S2 (see Figure 2a,d). Clinopyroxene relics are also sporadically associated with $\mathrm{Grt}_{1}$. $\mathrm{Spl}_{1}$ and spinel in the host rock are also related to this stage or developed earlier. We assume that the core of $\mathrm{Grt}_{2}$ refers to this stage.

Stage II is a composite stage that we tentatively divided into two substages $(a, b)$. Stage IIa is related to the formation of a "reaction rim", mainly made up of Amp between the garnet vein and the host rock. The Amp-rich reaction rim is characterized by the presence of symplectitic Amp and $\mathrm{Spl}_{2}$ (Figure 5b) as described for the coronitic microstructures in Layer B rocks (see Figure 6d, p. 168 in [35]). Stage IIb led to the formation of the Grt 2 mantle in the core of the vein (Figure 5c) with $\mathrm{Ep}_{1}$ in Grt 2 . We tentatively refer the formation of the $\mathrm{Grt}_{2}$ rim to this stage as well. The complex zoning of $\mathrm{Grt}_{2}$ porphyroblasts suggests, in turn, a complex evolution during Stage II. 

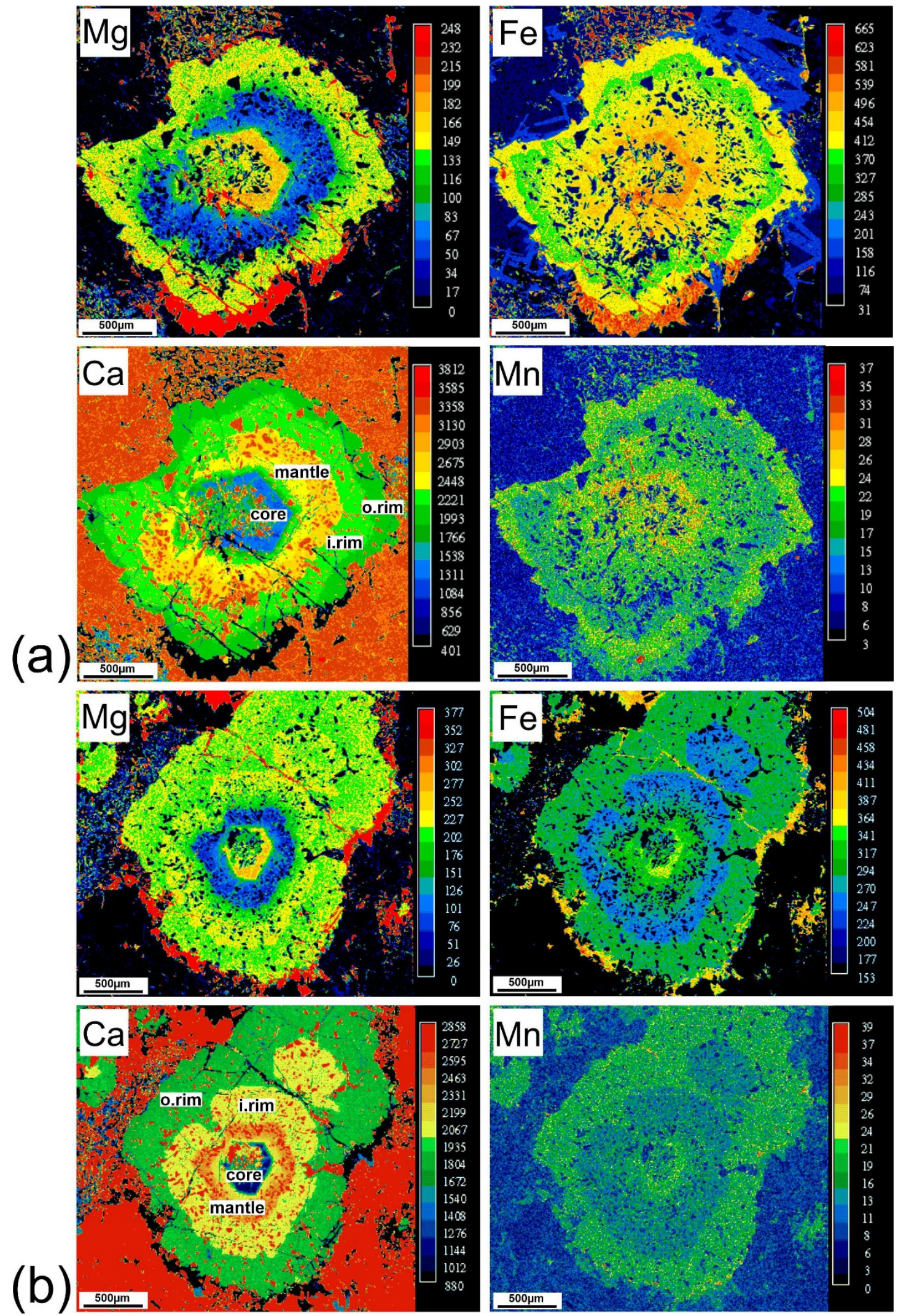

Figure 6. $\mathrm{Mg}, \mathrm{Fe}, \mathrm{Ca}$, and $\mathrm{Mn}$ concentration maps of a selected garnet (Grt2) crystal from sample (a) MN21V and (b) MN22. The scales for the color codes on the right-hand side of each image indicate counts of specific $\mathrm{X}$-ray radiation per time unit. 
Stage III is related to the widespread formation of $\mathrm{Ep}_{2}$ and $\mathrm{Ep}_{3}$, which locally grew in the center of the garnet-rich veins (Figure 5d). Epidote also occurs as filling material in millimetric-to-sub-millimetric late cracks. The growth of Crn and Mrg is also related to Stage III.

\subsection{Mineral Composition of Vein Samples}

Microprobe analyses of garnet, amphibole, chlorite, epidote, spinel, and margarite from garnet vein samples MN50A, MN21V, and MN22 are reported in Tables 1 and 2, respectively.

Garnet-Two textural types of garnet were analyzed $\left(\mathrm{Grt}_{1}\right.$ and $\left.\mathrm{Grt}_{2}\right)$. Grt $\mathrm{Gr}_{1}$ is rich in almandine $\left(\mathrm{Alm}_{41-45}\right)$ and poor in spessartine ( $\left.\mathrm{Sps}_{2-3}\right)$, with intermediate grossular $\left(\mathrm{Grs}_{24-29}\right)$ and pyrope $\left(\operatorname{Prp}_{26-29}\right)$ contents. The $\mathrm{Grt}_{1}$ composition is fairly constant within the same garnet-rich vein; nevertheless, Grt ${ }_{1}$ shows a very slight patchy zoning (Figure $4 b$ ) in which most compositional differences are within the analytical error. Small compositional differences (no more than 2-4 mol.\%) have also been observed when comparing $\mathrm{Grt}_{1}$ from different veins. Grt ${ }_{2}$ shows a well-defined compositional zoning from core to rim, as documented by $\mathrm{X}$-ray maps in Figure 6a,b. Four domains (core, mantle, inner rim, and outer rim) are clearly recognizable (Figure 6, Tables 1 and 2). The euhedral-shaped $\mathrm{Grt}_{2}$ core is $\mathrm{Alm}_{49} \mathrm{Grs}_{21-22} \operatorname{Prp}_{27-29} \mathrm{Sps}_{1}$. A significant and abrupt increase in Grs component from core to mantle $\left(\mathrm{Alm}_{41} \mathrm{Grs}_{50-52} \mathrm{Prp}_{6-7} \mathrm{Sps}_{1}\right)$ can be observed. The Grt inner and outer rim are $\mathrm{Alm}_{34-36} \mathrm{Grs}_{42} \operatorname{Prp}_{22-23} \mathrm{Sps}_{1}$ and $\mathrm{Alm}_{39-40} \mathrm{Grs}_{37} \operatorname{Prp}_{22} \mathrm{Sps}_{1}$, respectively. Several spot analyses acquired with the EMP in the different $\mathrm{Grt}_{2}$ domains illustrate the chemical evolution of zoned garnet (Figure 7). This diagram shows that the $\mathrm{Grt}_{2}$ core domain and Grt from the vein edge have similar compositions. The $\mathrm{Grt}_{2}$ inner and outer rims also display similar compositions. The $\mathrm{Grt}_{2}$ mantle stands out for a significant difference in composition, characterized by high $\mathrm{X}_{\mathrm{Ca}}$ and very low $\mathrm{X}_{\mathrm{Mg}}$ values (Figure $7 \mathrm{a}, \mathrm{b}$ ), with respect to other domain.

Table 1. Selected microprobe analyses (wt \%) of the main phases occurring in garnet-rich vein (samples MN50A and MN21V).

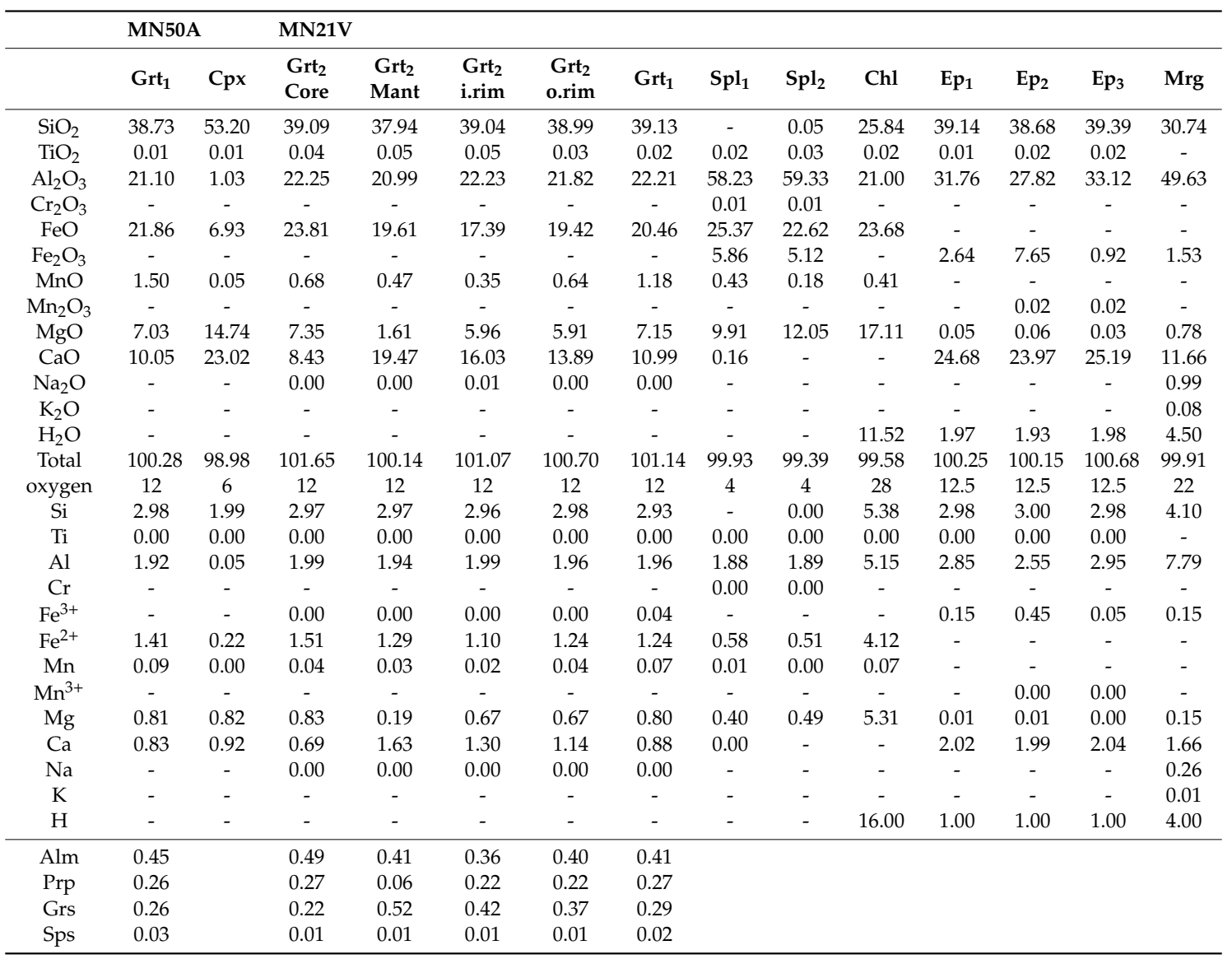


Table 2. Selected microprobe analyses (wt $\%$ ) of the main phases occurring in garnet-rich vein (sample MN22).

\begin{tabular}{|c|c|c|c|c|c|c|c|c|c|c|c|c|}
\hline & \multicolumn{12}{|l|}{ MN22 } \\
\hline & $\begin{array}{l}\mathrm{Grt}_{2} \\
\text { Core }\end{array}$ & $\begin{array}{c}\mathrm{Grt}_{2} \\
\text { Mant }\end{array}$ & $\begin{array}{l}\mathrm{Grt}_{2} \\
\text { i.rim }\end{array}$ & $\begin{array}{c}\mathrm{Grt}_{2} \\
\text { o.rim }\end{array}$ & Grt $_{1}$ & $\mathrm{Spl}_{1}$ & $\mathrm{Spl}_{2}$ & Chl & $E p_{1}$ & $\mathrm{Ep}_{2}$ & $\mathrm{Ep}_{3}$ & Mrg \\
\hline $\mathrm{SiO}_{2}$ & 39.12 & 38.40 & 39.50 & 39.18 & 39.43 & - & 0.04 & 23.57 & 39.16 & 38.72 & 39.50 & 31.82 \\
\hline $\mathrm{TiO}_{2}$ & 0.07 & 0.04 & 0.07 & 0.07 & 0.02 & - & - & 0.03 & 0.03 & 0.04 & 0.01 & 0.01 \\
\hline $\mathrm{Al}_{2} \mathrm{O}_{3}$ & 22.42 & 21.52 & 22.23 & 21.29 & 21.81 & 58.12 & 60.12 & 24.43 & 31.73 & 28.11 & 33.77 & 49.43 \\
\hline $\mathrm{Cr}_{2} \mathrm{O}_{3}$ & - & 0.01 & 0.01 & - & - & - & - & - & - & - & - & - \\
\hline $\mathrm{FeO}$ & 23.90 & 20.38 & 16.53 & 18.98 & 21.58 & 25.52 & 22.24 & 27.56 & - & - & - & 0.21 \\
\hline $\mathrm{Fe}_{2} \mathrm{O}_{3}$ & - & - & - & - & - & 5.86 & 4.77 & - & 3.00 & 7.50 & 0.22 & - \\
\hline $\mathrm{MnO}$ & 0.60 & 0.44 & 0.36 & 0.57 & 1.62 & 0.47 & 0.15 & 0.52 & - & - & - & - \\
\hline $\mathrm{Mn}_{2} \mathrm{O}_{3}$ & - & - & - & - & - & - & - & - & 0.04 & 0.02 & - & - \\
\hline $\mathrm{MgO}$ & 7.78 & 1.78 & 6.39 & 6.14 & 7.72 & 9.79 & 12.44 & 12.51 & 0.06 & 0.08 & - & 0.18 \\
\hline $\mathrm{CaO}$ & 7.79 & 18.73 & 16.34 & 14.11 & 9.09 & 0.11 & 0.03 & - & 24.39 & 23.99 & 24.94 & 12.34 \\
\hline $\mathrm{Na}_{2} \mathrm{O}$ & 0.03 & - & 0.01 & - & 0.04 & - & - & - & 0.02 & - & - & 0.61 \\
\hline $\mathrm{K}_{2} \mathrm{O}$ & - & - & - & 0.03 & - & - & - & - & - & - & - & 0.58 \\
\hline $\mathrm{H}_{2} \mathrm{O}$ & - & - & - & - & - & - & - & 11.35 & 1.97 & 1.94 & 1.99 & 4.33 \\
\hline Total & 101.60 & 101.30 & 101.42 & 100.35 & 101.34 & 99.88 & 99.79 & 99.97 & 100.41 & 100.40 & 100.43 & 99.61 \\
\hline oxygen & 12 & 12 & 12 & 12 & 12 & 4 & 4 & 28 & 12.5 & 12.5 & 12.5 & 22 \\
\hline $\mathrm{Si}$ & 2.97 & 2.97 & 2.97 & 2.99 & 2.97 & - & 0.00 & 4.98 & 2.98 & 2.99 & 2.98 & 4.41 \\
\hline $\mathrm{Ti}$ & 0.00 & 0.00 & 0.00 & 0.00 & 0.00 & - & - & 0.00 & 0.00 & 0.00 & 0.00 & 0.00 \\
\hline $\mathrm{Al}$ & 1.99 & 1.96 & 1.97 & 1.92 & 1.93 & 1.88 & 1.90 & 6.08 & 2.85 & 2.56 & 3.00 & 8.06 \\
\hline $\mathrm{Cr}$ & - & 0.00 & 0.00 & - & - & - & - & - & - & - & - & - \\
\hline $\mathrm{Fe}^{3+}$ & - & - & - & - & 0.07 & 0.12 & 0.10 & - & 0.17 & 0.43 & 0.01 & - \\
\hline $\mathrm{Fe}^{2+}$ & 1.51 & 1.32 & 1.04 & 1.22 & 1.29 & 0.58 & 0.50 & 4.87 & - & - & - & 0.02 \\
\hline $\mathrm{Mn}$ & 0.04 & 0.03 & 0.02 & 0.04 & 0.10 & 0.01 & 0.00 & 0.09 & - & - & - & - \\
\hline $\mathrm{Mn}^{3+}$ & - & - & - & - & - & - & - & - & 0.00 & 0.00 & - & - \\
\hline $\mathrm{Mg}$ & 0.88 & 0.20 & 0.72 & 0.70 & 0.87 & 0.40 & 0.49 & 3.94 & 0.01 & 0.01 & - & 0.04 \\
\hline $\mathrm{Ca}$ & 0.63 & 1.55 & 1.32 & 1.16 & 0.73 & 0.00 & 0.00 & - & 1.99 & 1.99 & 2.02 & 1.83 \\
\hline $\mathrm{Na}$ & 0.00 & - & 0.00 & - & 0.01 & - & - & - & 0.00 & - & - & 0.16 \\
\hline $\mathrm{K}$ & - & - & - & 0.00 & - & - & - & - & - & - & - & 0.10 \\
\hline $\mathrm{H}$ & - & - & - & - & - & - & - & 16.00 & 1.00 & 1.00 & 1.00 & 4.00 \\
\hline Alm & 0.49 & 0.42 & 0.34 & 0.39 & 0.43 & & & & & & & \\
\hline Prp & 0.29 & 0.07 & 0.23 & 0.23 & 0.29 & & & & & & & \\
\hline Grs & 0.21 & 0.50 & 0.43 & 0.37 & 0.24 & & & & & & & \\
\hline Sps & 0.01 & 0.01 & 0.01 & 0.01 & 0.03 & & & & & & & \\
\hline
\end{tabular}

Pyroxene-The rare clinopyroxene is diopside with $\mathrm{X}_{\mathrm{Mg}} \sim 0.78$ and $\mathrm{Al}$ content of 0.05 atoms per formula unit (apfu).

Amphibole-According to the amphibole supergroup classification IMA 2012 [38], the amphibole of the host rock, associated with spinel outside the garnet vein, is Mg-hornblende with $\mathrm{Si}=6.5-6.6$ atoms per formula unit (apfu) and $\mathrm{X}_{\mathrm{Mg}}=0.92-0.93$. The amphibole replacing garnet in the veins is Mg-hornblende with $\mathrm{X}_{\mathrm{Mg}}=0.89$.

Spinel-Two textural types of spinel were analyzed $\left(\mathrm{Spl}_{1}\right.$ and $\left.\mathrm{Spl}_{2}\right)$. Spl $\mathrm{Sp}_{1}$ belongs to the spinel-hercynite series, with an $\mathrm{X}_{\mathrm{Mg}}$ around 0.41 and undetectable $\mathrm{Cr}_{2} \mathrm{O}_{3}$ content. $\mathrm{Spl}_{2}$ also belongs to the spinel-hercynite series, with an $\mathrm{X}_{\mathrm{Mg}}$ of $0.48-0.50$ and a $\mathrm{Cr}_{2} \mathrm{O}_{3}$ content around $0.02 \mathrm{wt} \%$.

Epidote-The three textural types of epidote $\left(\mathrm{Ep}_{1}, \mathrm{Ep}_{2}\right.$, and $\left.\mathrm{Ep}_{3}\right)$ differ by their iron content. $\mathrm{Ep}_{1}$ shows $\mathrm{Fe}_{2} \mathrm{O}_{3}$ contents from 2.6 to $3.0 \mathrm{wt} \%$ (0.15-0.17 apfu). Ep 2 contains higher iron contents $\left(\mathrm{Fe}^{3+}\right.$ up to $0.45 \mathrm{apfu}$ ) and lower $\mathrm{Al}_{2} \mathrm{O}_{3}$ (around $27 \mathrm{wt} \%$ ). Ep 3 contains low iron contents $\left(\mathrm{Fe}^{3+}<0.08 \mathrm{apfu}\right.$ ). All epidote varieties belong to the clinozoisite-epidote series.

Margarite-The margarite from the patches is characterized by small amounts of Fe and $\mathrm{K}$ $(\mathrm{Fe}=0.02-0.22 \mathrm{apfu} ; \mathrm{K}=0.01-0.10 \mathrm{apfu})$ and Na content of 0.2-0.4 apfu.

Chlorite-The chlorite growing on the garnet cracks or in the epidote-rich matrix has $\mathrm{Si}$ values from 4.9 to 5.3 apfu and $\mathrm{Fe}_{\text {tot }}$ contents between 4.1 and 5.3 apfu. 

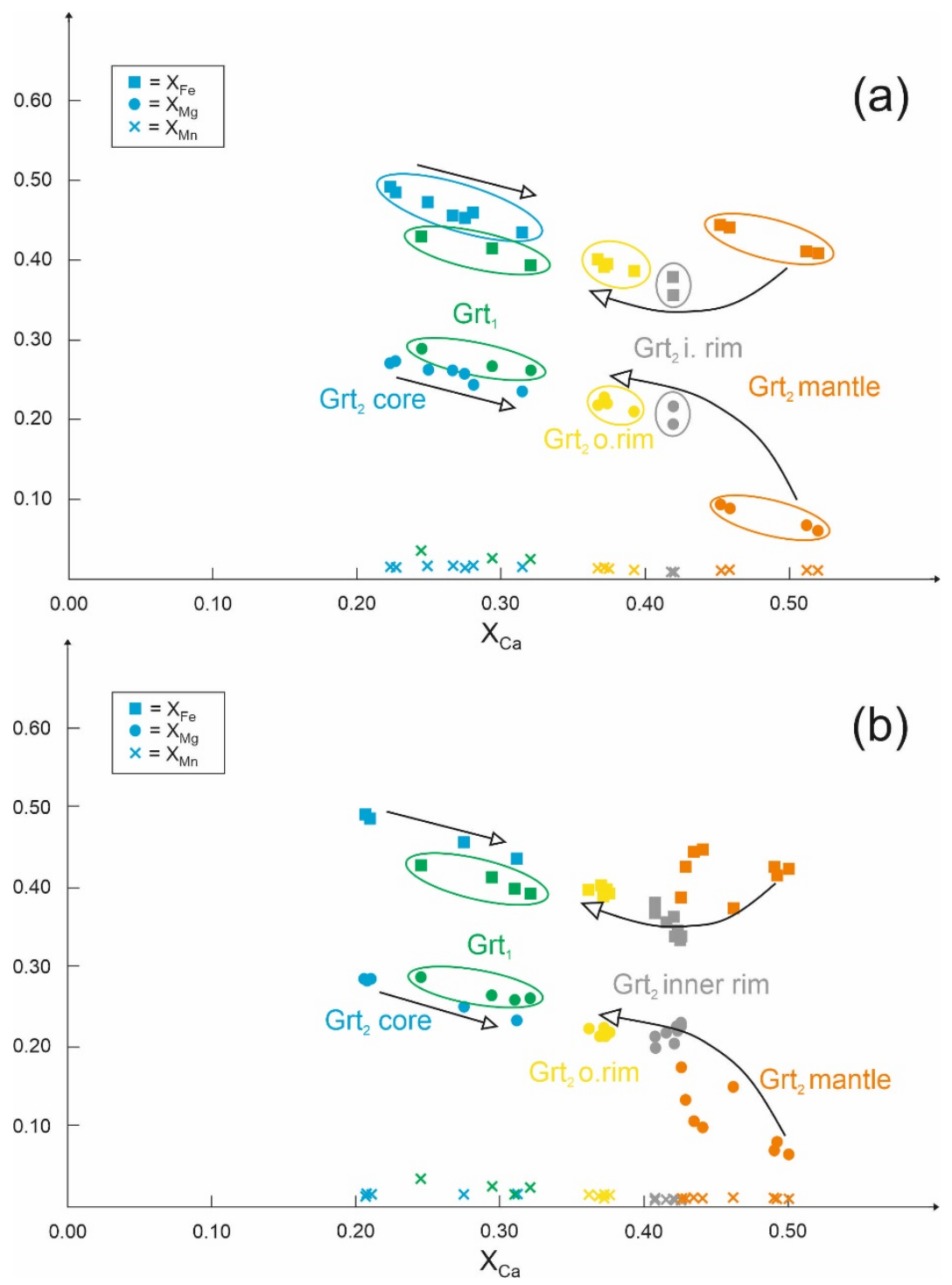

Figure 7. Chemical composition of garnet from vein samples (a) MN21V and (b) MN22, displayed in terms of molar fractions of grossular and pyrope/almandine/spessartine. The circles discern the different garnet types shown in Figure 6a,b.

\section{Derivation of P-T Conditions}

\subsection{P-T Conditions of the Host Rock}

We estimated the $\mathrm{P}-\mathrm{T}$ conditions for the rocks from Layer $\mathrm{C}$, containing the veins, by applying the $\mathrm{P}-\mathrm{T}$ pseudosection approach in the NCKFMASH $+\mathrm{Ti}+\mathrm{Mn}$ system. For this purpose, we used the software package PERPLE_X [39,40] and the thermodynamic data set of [41] for $\mathrm{H}_{2} \mathrm{O}$ and minerals. The solid-solution models are those of [42] (garnet, epidote, white mica, spinel, and olivine), [43] (orthopyroxene), [44] (clinopyroxene), [45] (chlorite), [46] (biotite and potassic white mica), [47] (amphibole), and [48] (plagioclase). In addition, the ideal mixing model IlGkPy for ilmenite was applied. All the $\mathrm{P}-\mathrm{T}$ pseudosections were calculated considering $\mathrm{H}_{2} \mathrm{O}$ as a saturated component and iron as divalent only.

The bulk-rock composition used to calculate the P-T pseudosection was obtained by averaging a total of ten $2 \times 2 \mathrm{~mm}$ SEM-EDS area-scan analyses on thin sections of a rock sample from Layer $\mathrm{C}$. The obtained bulk-rock composition was then corrected for apatite by reducing the $\mathrm{CaO}$ values according to the analyzed $\mathrm{P}_{2} \mathrm{O}_{5}$ content and finally normalizing to $100 \mathrm{wt} . \%$. The composition used in 
the $\mathrm{P}-\mathrm{T}$ pseudosection calculation is (in wt. \%): $\mathrm{SiO}_{2}=45.62 ; \mathrm{Al}_{2} \mathrm{O}_{3}=15.79 ; \mathrm{TiO}_{2}=0.62 ; \mathrm{FeO}=11.54$; $\mathrm{MgO}=10.26 ; \mathrm{MnO}=0.13 ; \mathrm{CaO}=14.73 ; \mathrm{Na}_{2} \mathrm{O}=1.08 ; \mathrm{K}_{2} \mathrm{O}=0.23$. The resulting $\mathrm{P}-\mathrm{T}$ pseudosection is shown in Figure 8. The intersections of isopleths for the almandine, pyrope, and grossular components $\left(\mathrm{Alm}_{41}, \operatorname{Prp}_{27}\right.$, and $\left.\mathrm{Grs}_{29}\right)$ in the garnet and $\mathrm{X}_{\mathrm{Mg}}$ of clinopyroxene $(0.86-0.89)$ occur in the range $\mathrm{T}=650-750{ }^{\circ} \mathrm{C}, \mathrm{P}=1.0-1.7 \mathrm{GPa}$ (Figure 8).

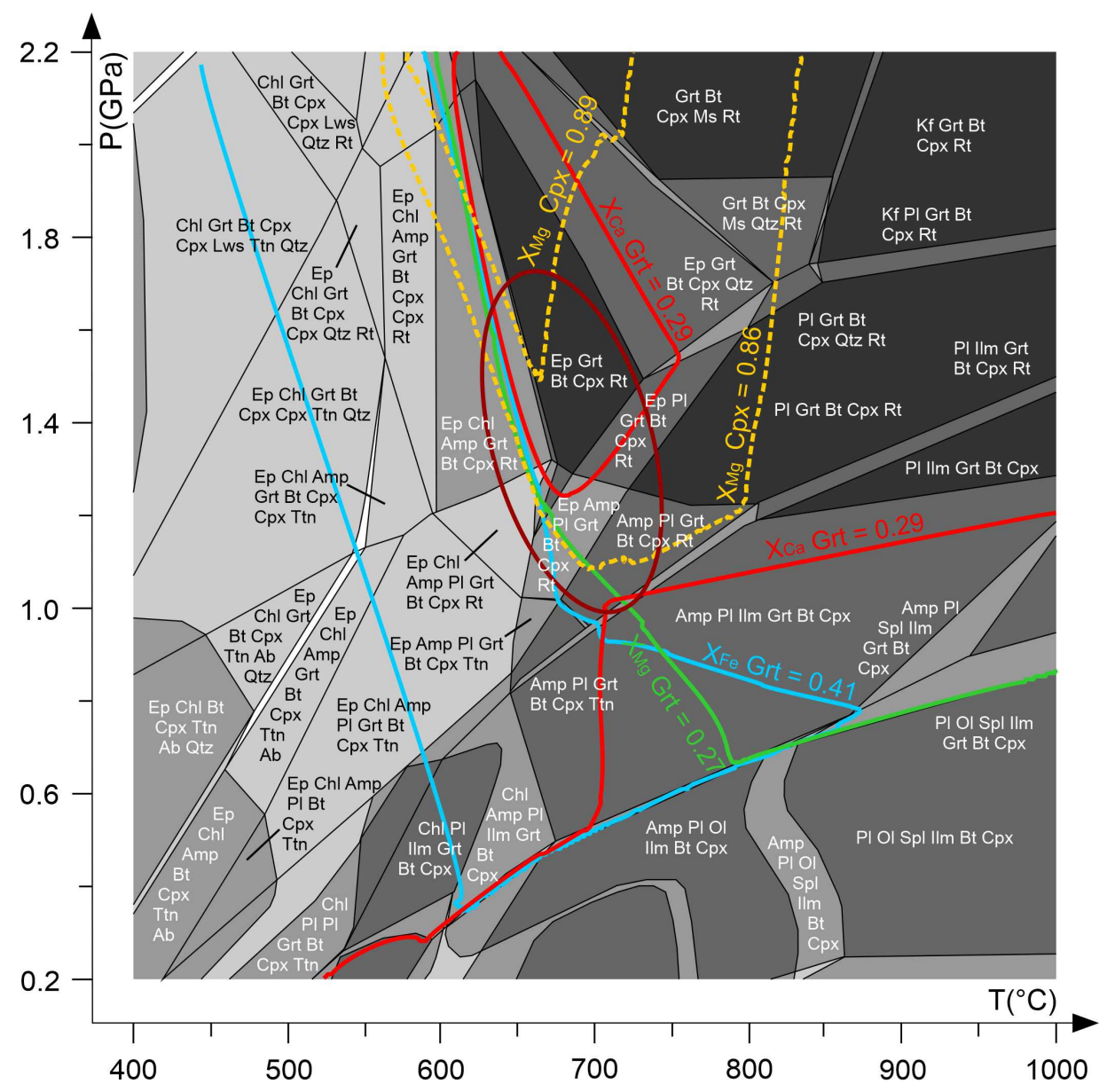

Figure 8. P-T pseudosection calculated in the NCKFMASH $+\mathrm{Ti}+\mathrm{Mn}$ system for the bulk rock composition of the host rock (ultrabasic amphibolite, Layer $\mathrm{C}$ ), and estimated $\mathrm{P}-\mathrm{T}$ conditions for the growth of garnet in host rock (purple ellipse). Blue, green, and red lines show the almandine $\left(\mathrm{X}_{\mathrm{Fe}}=\mathrm{Fe} / \mathrm{Fe}+\mathrm{Mg}+\mathrm{Mn}+\mathrm{Ca}\right)$, pyrope $\left(\mathrm{X}_{\mathrm{Mg}}=\mathrm{Mg} / \mathrm{Fe}+\mathrm{Mg}+\mathrm{Mn}+\mathrm{Ca}\right)$, and grossular $\left(\mathrm{X}_{\mathrm{Ca}}=\mathrm{Ca} / \mathrm{Fe}\right.$ $+\mathrm{Mg}+\mathrm{Mn}+\mathrm{Ca})$ components in garnet. Yellow dashed lines show the $\mathrm{X}_{\mathrm{Mg}}$ ratio $(\mathrm{Mg} / \mathrm{Mg}+\mathrm{Fe})$ in clinopyroxene.

\subsection{P-T Conditions for Stages I, II, and III of the Garnet Veins}

The temperature conditions of Stage I were determined with the garnet-clinopyroxene geothermometer using garnet-clinopyroxene pairs in mutual contact in sample MN50A. We obtained temperatures between 680 and $760{ }^{\circ} \mathrm{C}$ using different thermometer calibrations [49-52]. The P-T conditions for Stage II, corresponding to the widespread formation of amphibole in both veins and host rock, can be related to the amphibolite facies documented for the ultrabasic amphibolites and the adjacent banded amphibolites $[34,35,53]$. We applied the garnet-hornblende thermometer using the chemical composition of amphibole and $\mathrm{Grt}_{1}$ in mutual contact at the edge of the vein. The calibrations of $[54,55]$ yielded temperatures in the range of $550-640{ }^{\circ} \mathrm{C}$. These conditions are comparable to those estimated for the same stage in other metabasites from NE Sardinia $[17,34,35]$. The P-T conditions for Stage III, corresponding to the local yet remarkable growth of epidote in the vein system, can 
be ascribed to the greenschist facies. The authors of [34] documented the coexistence of tremolite (locally replacing hornblende), chlorite, and epidote for the host rocks, suggesting a re-equilibration at temperatures from 330 to $400{ }^{\circ} \mathrm{C}$ according to the facies boundaries (Figure 9) given by [56].

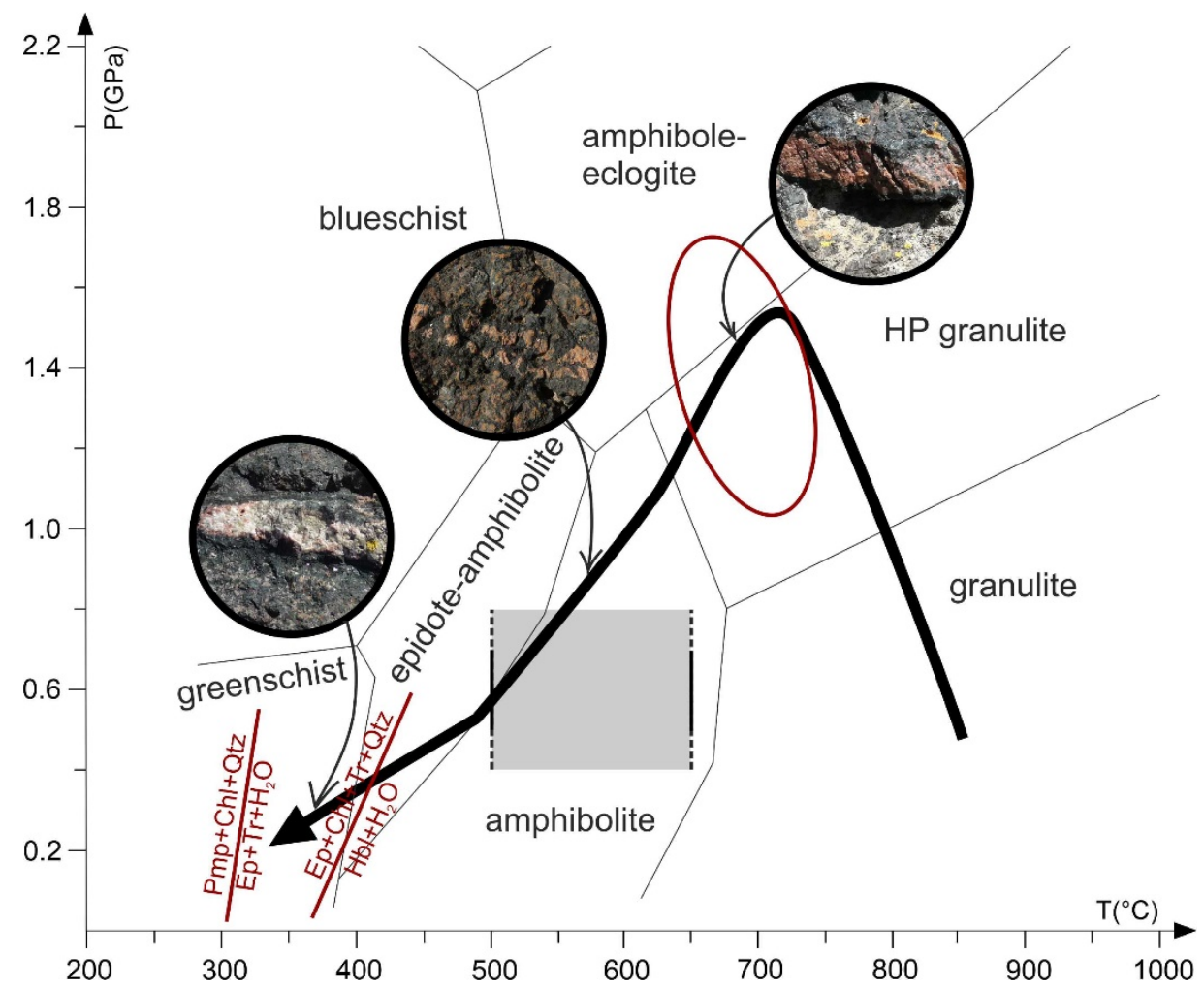

Figure 9. P-T path of the ultrabasic amphibolite documented by [35] (black arrow) compared with the $\mathrm{P}-\mathrm{T}$ conditions for the Grt1 veins (red ellipse) and the subsequent amphibole (grey area) and epidote (reaction curves from [56]) occurrences in the vein system. Photographs in circles graphically describe the textural evolution of the garnet veins.

\section{Discussion}

\subsection{Garnet Growth as Function of P-T Conditions and Fluid Influx}

It is difficult to ascertain the $\mathrm{P}-\mathrm{T}$ conditions of the garnet crystallization within the vein. It is also unclear as to whether the two main textural types of garnet recognized in the veins ( $\mathrm{Grt}_{1}$ and $\mathrm{Grt}_{2}$ ) grew contemporaneously or at different, possibly partly overlapping, times. However, the microstructural features and chemical compositions of the two garnet types suggest that they have formed by two different processes. Grt ${ }_{1}$ could have originated by the nucleation, growth, and coalescence of multiple fine-grained garnet crystals as reported by [57] for the formation of garnet porphyroblast in veins from the Sanbagawa metamorphic belt in Japan. The X-ray mapping of Grt $_{2}$ (see Figures 5 and 6) reveals the systematic occurrence of at least three garnet domains (core, mantle, and rim) separated by abrupt changes in composition and characterized by a significantly different content of mineral inclusions. Several micrometric epidote inclusions are strongly concentrated in the $\mathrm{Grt}_{2}$ mantle and scarce in the core and rim. These observations confirm that $\mathrm{Grt}_{2}$ consists of three individual domains, which probably formed at different times and under different $\mathrm{P}-\mathrm{T}$ conditions, infiltrated by different fluid compositions.

We think that in our case, garnet grew in response to changes along a $\mathrm{P}-\mathrm{T}$ trajectory that first intercepted a garnet-in reaction. Subsequently, garnet continued to grow as a function of the successive mineral equilibria that it encountered. The Ca-rich garnet mantle in $\mathrm{Grt}_{2}$, for example, was in equilibrium with a Ca-rich mineral assemblage, as documented by significant concentrations of 
epidote inclusions in this mantle (Figures $4 \mathrm{c}$ and 5). Furthermore, the core-rim profiles through Grt ${ }_{2}$ indicate that major boundaries of phase assemblage were overstepped and that the changing buffering assemblages cause subsequent garnet overgrowths to produce distinctly different zoning trends in $\mathrm{Fe}, \mathrm{Mg}, \mathrm{Ca}$, and $\mathrm{Mn}$. The diagram in Figure 6 reveals that (i) spessartine is the only component with constant content, and (ii) the composition of $\mathrm{Grt}_{1}$ partially overlaps the composition of the $\mathrm{Grt}_{2}$ core, whereas it is distinct from that of other $\mathrm{Grt}_{2}$ domains. The observation that spessartine is very low and almost constant along a core-rim profile reveals that $\mathrm{Mn}$ was not distinctly available in the system during garnet growth. The compositional similarities between the core of $\mathrm{Grt}_{2}$ and $\mathrm{Grt}_{1}$ suggest that they probably grew together during the same metamorphic stage and/or they formed in equilibrium with the same mineral assemblage. Although re-equilibration timescales can be significantly different for garnet growing in different rock compositions, the preservation of unmodified growth compositions in millimetric garnet requires prograde or exhumation events $<<5 \mathrm{Myr}$ in rocks reaching $650{ }^{\circ} \mathrm{C}$ or more [58].

The observation that garnet zoning in $\mathrm{Grt}_{2}$ does not follow a progressive change in composition from core to rim supports the hypothesis that the vein fill was produced at several stages of rock-fluid interaction that occurred during medium-to-high-temperature metamorphism of the ultrabasic amphibolites. The studied veins resemble "dilatation" veins (i.e., crack-seal veins) that developed due to rapid and transient brittle fracturing (hydrofracturing) as a consequence of fluid overpressure enhanced by a low permeability of wall rocks. The growth of crack-seal veins testifies to a fluid-closed system [59] with mass transfer at millimeter to meter scales from wall rock to vein, with hydrous fluids generated either by local devolatilization or in an external source. In the latter case, the fluid should have rapidly equilibrated with the host rock (e.g., [60]). At the outcrop scale, there is no evidence that hydrous fluids were generated in an external source. It is more likely that the fluids were already present in the basic-ultrabasic body at Mt. Nieddu. Alternatively, they could have been supplied by an external source with mobility limited to tens or hundreds of meters in distance. If successive garnet growth resulted each time from the deviation from equilibrium conditions caused by the influx of an external fluid, this influx would have acted several times, throughout a cyclic supply of aqueous fluids during the retrograde evolution and exhumation of the ultrabasic amphibolites. Thus, the vein system in the ultrabasic amphibolites provides evidence of cyclic hydrofracturing through rapid and transient events (e.g., crack-seal veining), with the growth of multiple vein-filling mineral assemblages during separate vein cycles and very restricted interconnectivity between fractures at any time.

\subsection{Metamorphic Evolution}

Garnet veins formed close to peak pressure conditions during the Variscan orogeny for the following reasons: (1) The general orientation of garnet veins is sub-parallel to the regional foliation; this indicates that most of these veins formed before the development of the main foliation and, thus, before the retrograde equilibration under amphibolite-facies conditions. (2) The coronitic garnet in the rocks of Layer B formed at the HP stage of the development of corona microtextures. The metamorphic evolution and the P-T path of the Mt. Nieddu ultrabasic amphibolite were reconstructed by $[35,61]$ through thermodynamic modelling via $\mathrm{P}-\mathrm{T}$ pseudosections and conventional thermobarometry on such textures in selected samples from Layer B. The authors of [35] documented that the ultrabasic amphibolites underwent an anticlockwise $\mathrm{P}-\mathrm{T}$ path that started with an igneous stage followed by progressive cooling to granulite-, amphibolite-, and greenschist-facies conditions. During the cooling towards the granulite-facies conditions, these rocks experienced a pressure increase up to HP granulite conditions (according to the scheme by [56]) of 1.3-1.7 GPa at $\mathrm{T}=680-730{ }^{\circ} \mathrm{C}$ (black arrow in Figure 9). The P-T conditions of $\mathrm{T}=650-750^{\circ} \mathrm{C}$ and $\mathrm{P}=1.0-1.7 \mathrm{GPa}$, derived here for the formation of $\mathrm{Grt}_{1}$, match the metamorphic peak and confirm that these veins formed under HP conditions (red ellipse in Figure 9). Subsequently, the studied rocks were exhumed accompanied by cooling and, thus, passed through the fields of the amphibolite and greenschist facies. The garnet veins reacted by the overgrowth 
of an amphibole reaction-rim and the growth of late epidote. These mineralogical changes resulted in the here-called "composite veins". The P-T conditions for the amphibolite stage were quantified by [53] for the adjacent amphibolite at Mt. Nieddu, which are also similar for several metabasites from NE Sardinia (at $\mathrm{T}=500-600^{\circ} \mathrm{C}$ and $\mathrm{P}=0.4-0.8 \mathrm{GPa}$ ) $[17,34]$. The greenschist-facies conditions can be qualitatively ascribed to $\mathrm{P}=0.2-0.3 \mathrm{GPa}$ and $\mathrm{T}=300-350{ }^{\circ} \mathrm{C}$ [34].

The P-T conditions documented in this work for garnet vein formation and by [35] for the host rocks are illustrated in Figure 9. In brief, the garnet vein system in the ultrabasic amphibolites of Mt. Nieddu formed during retrograde metamorphism, evolving trough different cycles of fluid flux during the exhumation of the ultrabasic amphibolites at the end of the Variscan orogeny. The only existing geochronological data on the studied rocks are the $\mathrm{U}-\mathrm{Pb}$ isotopic data on matrix rutile from ultrabasic amphibolite, giving a lower intercept in the Tera-Wasserburg diagram of $273 \pm 13$ Ma [62]. The considered geodynamic scenario of the studied rocks is reported in [53] for the adjacent amphibolites that host the ultrabasic amphibolites. Their igneous protolith was intruded into the lowermost portion of the upper plate, detached by tectonic erosion, accreted to the downgoing plate, and subducted to depths of 45-50 km. An increasing fluid pressure in the subduction channel could have favored the early formation of mono- and polymineralic veins. Subsequently, the ultrabasic amphibolites were exhumed, together with slices from both upper and lower plates, in an exhumation channel, where retrograde metamorphism took place. The flow of retrogression-related fluids along the plate interface likely facilitated the development of shear zones and fault systems and decreased the rock density, which consequently promoted the fluid circulation within the vein system as well as the uplift of the studied HP metamorphic rocks.

\section{Concluding Remarks}

The ultrabasic amphibolites of Mt. Nieddu, NW Sardinia, are crosscut by a complex vein system that is mainly composed of garnet-rich veins and formed during the granulite facies at the peak of metamorphism $\left(\mathrm{P}=1.0-1.7 \mathrm{GPa}, \mathrm{T}=650-750^{\circ} \mathrm{C}\right)$. Afterwards, these veins experienced two main stages of mineralogical re-equilibration with the formation of amphibole and, subsequently, epidote. The metamorphic evolution of the garnet-rich veins matches that of the host ultrabasic amphibolite. The vein system developed through different steps during the exhumation of the ultrabasic amphibolites in the course of the continental collision between Laurussia and Gondwana at the end of the Variscan orogen.

Author Contributions: Conceptualization, writing-review and editing, G.C., M.F., H.-J.M., G.M. and M.S.; software, M.S.; funding acquisition, M.F., G.C. All authors have read and agreed to the published version of the manuscript.

Funding: Financial support was provided by Regione Autonoma della Sardegna, L.R. 7/2007, research program "Il blocco Sardo-Corso: area chiave per la ricostruzione della geodinamica varisica" CUP J81G17000110002, and by the Fondazione di Sardegna research program "Geogenic and anthropogenic sources of minerals and elements: fate and persistency over space and time in sediments" CUP F74I19000960007.

Acknowledgments: T. Theye supported our EMP work at Universität Stuttgart. The authors are grateful to three anonymous reviewers that improved the final version of the manuscript.

Conflicts of Interest: The authors declare no conflict of interest.

\section{References}

1. Manning, C.E. The solubility of quartz in $\mathrm{H}_{2} \mathrm{O}$ in the lower crust and upper mantle. Geochim. Cosmochim. Acta 1994, 58, 4831-4839. [CrossRef]

2. Verlaguet, A.; Goffé, B.; Brunet, F.; Poinssot, C.; Vidal, O.; Findling, N.; Menut, D. Metamorphic veining and mass transfer in a chemically closed system: A case study in Alpine metabauxites (western Vanoise). J. Metamorph. Geol. 2011, 29, 275-300. [CrossRef]

3. Rauchenstein-Martinek, K.; Wagner, T.; Wälle, M.; Heinrich, C.A.; Arlt, T. Chemical evolution of metamorphic fluids in the Central Alps, Switzerland: Insight from LA-ICPMS analysis of fluid inclusions. Geofluids 2016, 16, 877-908. [CrossRef] 
4. Liu, P.L.; Massonne, H.-J.; Harlov, D.E.; Jin, Z.M. High-pressure fluid-rock interaction and mass transfer during exhumation of deeply subducted rocks: Insights from an eclogite-vein system in the ultrahigh-pressure terrane of the Dabie Shan, China. G-Cubed 2019, 20, 5786-5817. [CrossRef]

5. Groppo, C.; Compagnoni, R. Metamorphic veins from the serpentinites of the Piemonte Zone, western Alps, Italy: A review. Per. Miner. 2007, 76, 127-153.

6. Carmignani, L.; Carosi, R.; Di Pisa, A.; Gattiglio, M.; Musumeci, G.; Oggiano, G.; Pertusati, P.C. The Hercynian chain in Sardinia (Italy). Geodin. Acta 1994, 5, 217-233. [CrossRef]

7. Carmignani, L.; Oggiano, G.; Barca, S.; Conti, P.; Eltrudis, A.; Funedda, A.; Pasci, S.; Salvadori, I. Geologia della Sardegna. Note illustrative della Carta Geologica della Sardegna in scala 1:200,000. Mem. Descr. Carta Geol. Ital. 2001, 60, 283.

8. Cruciani, G.; Franceschelli, M.; Musumeci, G.; Spano, M.E.; Tiepolo, M. U-Pb zircon dating and nature of metavolcanics and metarkoses from the Monte Grighini Unit: New insights on Late Ordovician magmatism in the Variscan belt in Sardinia, Italy. Int. J. Earth Sci. 2013, 102, 2077-2096. [CrossRef]

9. Cruciani, G.; Franceschelli, M.; Massonne, H.-J.; Musumeci, G.; Spano, M.E. Thermomechanical evolution of the high-grade core in the nappe zone of Variscan Sardinia, Italy: The role of shear deformation and granite emplacement. J. Metamorph. Geol. 2016, 34, 321-342. [CrossRef]

10. Cruciani, G.; Franceschelli, M.; Puxeddu, M.; Tiepolo, M. Metavolcanics from Capo Malfatano, SW Sardinia, Italy: New insight on the age and nature of Ordovician volcanism in the Variscan foreland zone. Geol. J. 2018, 53, 1573-1585. [CrossRef]

11. Massonne, H.-J.; Cruciani, G.; Franceschelli, M.; Musumeci, G. Anticlockwise pressure-temperature paths record Variscan upper-plate exhumation: Example from micaschists of the Porto Vecchio region, Corsica. J. Metamorph. Geol. 2018, 36, 55-77. [CrossRef]

12. Cruciani, G.; Fancello, D.; Franceschelli, M.; Scodina, M.; Spano, M.E. Geothermobarometry of Al-silicate bearing migmatites from the Variscan chain of NE Sardinia, Italy: A P-T pseudosection approach. Per. Miner. 2014, 83, 19-40.

13. Cruciani, G.; Franceschelli, M.; Foley, S.F.; Jacob, D.E. Anatectic amphibole and restitic garnet in Variscan migmatite from NE Sardinia, Italy: Insights into partial melting from mineral trace elements. Eur. J. Miner. 2014, 26, 381-395. [CrossRef]

14. Massonne, H.-J.; Cruciani, G.; Franceschelli, M. Geothermobarometry on anatectic melts-A high-pressure Variscan migmatite from northeast Sardinia. Int. Geol. Rev. 2013, 55, 1490-1505. [CrossRef]

15. Fancello, D.; Cruciani, G.; Franceschelli, M.; Massonne, H.-J. Trondhjemitic leucosomes in paragneisses from NE Sardinia: Geochemistry and P-T conditions of melting and crystallization. Lithos 2018, 304, 501-517. [CrossRef]

16. Franceschelli, M.; Puxeddu, M.; Cruciani, G.; Dini, A.; Loi, M. Layered amphibolite sequence in NE Sardinia, Italy: Remnant of a pre-Variscan mafic-silicic layered intrusion? Contrib. Miner. Petrol. 2005, 149, 164-180. [CrossRef]

17. Franceschelli, M.; Puxeddu, M.; Cruciani, G.; Utzeri, D. Metabasites with eclogite facies relics from Variscides in Sardinia, Italy: A review. Int. J. Earth Sci. 2007, 96, 795-815. [CrossRef]

18. Cruciani, G.; Franceschelli, M.; Groppo, C. P-T evolution of eclogite-facies metabasite from NE Sardinia, Italy: Insights into the prograde evolution of Variscan eclogites. Lithos 2011, 121, 135-150. [CrossRef]

19. Cruciani, G.; Franceschelli, M.; Groppo, C.; Oggiano, G.; Spano, M.E. Re-equilibration history and P-T path of eclogites from Variscan Sardinia, Italy: A case study from the medium-grade metamorphic complex. Int. J. Earth Sci. 2015, 104, 797-814. [CrossRef]

20. Cruciani, G.; Franceschelli, M.; Langone, A.; Puxeddu, M.; Scodina, M. Nature and age of pre-Variscan eclogite protoliths from the low- to medium-grade metamorphic complex of north-central Sardinia (Italy) and comparison with coeval Sardinian eclogites in the northern Gondwana context. J. Geol. Soc. 2015, 172, 792-807. [CrossRef]

21. Cruciani, G.; Franceschelli, M.; Massonne, H.-J.; Carosi, R.; Montomoli, C. Pressure-temperature and deformational evolution of high-pressure metapelites from Variscan NE Sardinia, Italy. Lithos 2013, 175, 272-284. [CrossRef]

22. Cappelli, B.; Carmignani, L.; Castorina, F.; Di Pisa, A.; Oggiano, G.; Petrini, R. A Variscan suture zone in Sardinia: Geological, geochemical evidence, Paleozoic Orogenies in Europe (special issue). Geodin. Acta 1992, 5, 101-118. [CrossRef] 
23. Cruciani, G.; Dini, A.; Franceschelli, M.; Puxeddu, M.; Utzeri, D. Metabasite from the Variscan belt in NE Sardinia, Italy: Within-plate OIB-like melts with very high $\mathrm{Sr}$ and low Nd isotope ratios. Eur. J. Miner. 2010, 22, 509-523. [CrossRef]

24. Cruciani, G.; Montomoli, C.; Carosi, R.; Franceschelli, M.; Puxeddu, M. Continental collision from two perspectives: A review of Variscan metamorphism and deformation in northern Sardinia. Per. Miner. 2015, 84, 657-699.

25. Carosi, R.; Frassi, C.; Iacopini, D.; Montomoli, C. Post collisional transpressive tectonics in northern Sardinia (Italy). J. Virtual Explor. 2005, 19, 1-18. [CrossRef]

26. Elter, F.M.; Padovano, M.; Kraus, R.K. The Variscan HT metamorphic rocks emplacement linked to the interaction between Gondwana and Laurussia plates: Structural constraints in NE Sardinia (Italy). Terra Nova 2010, 22, 369-377. [CrossRef]

27. Di Vincenzo, G.; Carosi, R.; Palmeri, R. The relationship between tectono-metamorphic evolution and argon isotope records in white mica: Constraints from in situ 40Ar-39Ar laser analysis of the Variscan basement of Sardinia. J. Petrol. 2004, 45, 1013-1043. [CrossRef]

28. Ferrara, G.; Rita, F.; Ricci, C.A. Isotopic age and tectonometamorphic history of the metamorphic basement of North-Eastern Sardinia. Contrib. Miner. Petrol. 1978, 68, 99-106. [CrossRef]

29. Corsi, B.; Elter, F.M. Eo-Variscan (Devonian?) melting in the High-Grade Metamorphic Complex of the NE Sardinia Belt (Italy). Geodin. Acta 2006, 19, 155-164. [CrossRef]

30. Casini, L.; Cuccuru, S.; Maino, M.; Oggiano, G.; Puccini, A.; Rossi, P. Structural map of Variscan northern Sardinia (Italy). J. Maps 2014, 11, 75-84. [CrossRef]

31. Casini, L.; Cuccuru, S.; Puccini, A.; Oggiano, G.; Rossi, P. Evolution of the Corsica-Sardinia Batholith and late-orogenic shearing of the Variscides. Tectonophysics 2015, 646, 65-78. [CrossRef]

32. Barca, S.; Carmignani, L.; Eltrudis, A.; Franceschelli, M. Origin and evolution of the Permian-Carboniferous basin of Mulargia Lake (South-Central Sardinia, Italy) related to the Late-Hercynian extensional tectonic. Comptes Rendus Acad. Sci. Paris 1995, 321, 171-178.

33. Ghezzo, C.; Memmi, I.; Ricci, C.A. Un evento granulitico nel basamento metamorfico della Sardegna nord-orientale. Mem. Soc. Geol. Ital. 1979, 20, 23-38.

34. Franceschelli, M.; Carcangiu, G.; Caredda, A.M.; Cruciani, G.; Memmi, I.; Zucca, M. Transformation of cumulate mafic rocks to granulite and re-equilibration in amphibolite and greenschist facies in NE Sardinia, Italy. Lithos 2002, 63, 1-18. [CrossRef]

35. Scodina, M.; Cruciani, G.; Franceschelli, M.; Massonne, H.-J. Multilayer corona textures in the high-pressure ultrabasic amphibolite of Mt. Nieddu, NE Sardinia (Italy): Equilibrium versus disequilibrium. Per. Miner. 2020, 89, 169-186.

36. Massonne, H.-J. Formation of amphibole and clinozoisite-epidote in eclogite owing to fluid infiltration during exhumation in a subduction channel. J. Petrol. 2012, 53, 1969-1998. [CrossRef]

37. Brandelik, A. CALCMIN-An EXCEL ${ }^{\mathrm{TM}}$ Visual Basic application for calculating mineral structural formulae from electron microprobe analyses. Comput. Geosci. 2009, 35, 1540-1551. [CrossRef]

38. Hawthorne, F.C.; Oberti, R.; Harlow, G.E.; Maresch, W.V.; Martin, R.F.; Schumacher, J.C.; Welch, M.D. IMA Report-Nomenclature of the amphibole supergroup. Am. Miner. 2012, 97, 2031-2048. [CrossRef]

39. Connolly, J.A.D. Multivariable phase diagrams: An algorithm based on generalized thermodynamics. Am. J. Sci. 1990, 290, 666-718. [CrossRef]

40. Connolly, J.A.D. The geodynamic equation of state: What and how. Geochem. Geophys. 2009, 10. [CrossRef]

41. Holland, T.J.B.; Powell, R. An improved and extended internally consistent thermodynamic dataset for phases of petrological interest, involving a new equation of state for solids. J. Metamorph. Geol. 2011, 29, 333-383. [CrossRef]

42. Holland, T.J.B.; Powell, R. An internally consistent thermodynamic data set for phases of petrological interest. J. Metamorph. Geol. 1998, 16, 309-343. [CrossRef]

43. Holland, T.J.B.; Powell, R. Thermodynamics of order-disorder in minerals, 2. Symmetric formalism applied to solid solutions. Am. Miner. 1996, 81, 1425-1437. [CrossRef]

44. Green, E.C.R.; Holland, T.J.B.; Powell, R. An order-disorder model for omphacitic pyroxenes in the system jadeite-diopside-hedenbergite-acmite with applications to eclogitic rocks. Am. Miner. 2007, 92, 1181-1189. [CrossRef] 
45. Holland, T.J.B.; Baker, J.M.; Powell, R. Mixing properties and activity-composition relationships of chlorites in the system $\mathrm{MgO}-\mathrm{FeO}-\mathrm{Al}_{2} \mathrm{O}_{3}-\mathrm{SiO}_{2}-\mathrm{H}_{2} \mathrm{O}$. Eur. J. Miner. 1998, 10, 395-406. [CrossRef]

46. Powell, R.; Holland, T. Relating formulations of the thermodynamics of mineral solid solutions: Activity modeling of pyroxenes, amphiboles, and micas. Am. Miner. 1999, 84, 1-14. [CrossRef]

47. Dale, J.; Powell, R.; White, R.W.; Elmer, F.L.; Holland, T.J.B. A thermodynamic model for Ca-Na clinoamphiboles in $\mathrm{Na}_{2} \mathrm{O}-\mathrm{CaO}-\mathrm{FeO}-\mathrm{MgO}-\mathrm{Al}_{2} \mathrm{O}_{3}-\mathrm{SiO}_{2}-\mathrm{H}_{2} \mathrm{O}-\mathrm{O}$ for petrological calculations. J. Metamorph. Geol. 2005, 23, 771-791. [CrossRef]

48. Newton, R.C.; Charlu, T.V.; Kleppa, O.J. Thermochemistry of the high structural state plagioclases. Geochim. Cosmochim. Acta 1981, 44, 933-941. [CrossRef]

49. Ellis, D.J.; Green, D.H. An experimental study of the effect of Ca upon garnet-clinopyroxene Fe-Mg exchange equilibria. Contrib. Miner. Petrol. 1979, 71, 13-22. [CrossRef]

50. Pattison, D.R.M.; Newton, R.C. Experimental calibration of the garnet-clinopyroxene Fe-Mg exchange thermometer. Contrib. Miner. Petrol. 1989, 101, 87-103. [CrossRef]

51. Krogh-Ravna, E. The garnet-clinopyroxene $\mathrm{Fe}^{2+}-\mathrm{Mg}$ geothermometer: An updated calibration. J. Metamorph Geol. 2000, 18, 211-219. [CrossRef]

52. Nakamura, D. A new formulation of garnet-clinopyroxene geothermometer based on accumulation and statistical analysis of a large experimental dataset. J. Metamorph. Geol. 2009, 27, 495-508. [CrossRef]

53. Scodina, M.; Cruciani, G.; Franceschelli, M.; Massonne, H.-J. Anticlockwise P-T evolution of amphibolites from NE Sardinia, Italy: Geodynamic implications for the tectonic evolution of the Variscan Corsica-Sardinia block. Lithos 2019, 324, 763-775. [CrossRef]

54. Krogh-Ravna, E. Distribution of Fe2q and $\mathrm{Mg}$ between coexisting garnet and hornblende in synthetic and natural systems: An empirical calibration of the garnet-hornblende Fe-Mg geothermometer. Lithos 2000, 53, 265-277. [CrossRef]

55. Perchuk, L.L.; Aranovich, L.Y.; Podlesskii, K.K.L.; Lavrent'eva, I.V.; Gerasimov, V.Y.; Fed'Kin, V.V.; Kitsul, V.I.; Karasokov, L.P.; Berdnikov, N.V. Precambrian granulites of the Aldan shield, eastern Siberia, USSR. J. Metamorph. Geol. 1985, 3, 265-310. [CrossRef]

56. Liou, J.G.; Zhang, R.Y.; Ernst, W.G.; Rumble, D., III; Maruyama, S. High-pressure minerals from deeply subducted metamorphic rocks. In Ultrahigh-Pressure Mineralogy; Hemley, R.J., Ed.; Walter de Gruyter: Berlin, Germany, 1998; Volume 37, pp. 33-96.

57. Okamoto, A.; Michibayashi, K. Misorientations of garnet aggregate within a vein: An example from the Sanbagawa metamorphic belt, Japan. J. Metamorph. Geol. 2006, 24, 353-366. [CrossRef]

58. Caddick, M.J.; Konopásek, J.; Thompson, A.B. Preservation of garnet growth zoning and the duration of prograde metamorphism. J. Petrol. 2010, 51, 2327-2347. [CrossRef]

59. Oliver, N.H.S. Review and classification of structural controls on fluid flow during regional metamorphism. J. Metamorph. Geol. 1996, 14, 477-492. [CrossRef]

60. Yardley, B.W.D.; Bottrell, S.H. Silica mobility and fluid movement during metamorphism of the Connemara. J. Metamorph. Geol. 1992, 10, 453-464. [CrossRef]

61. Cruciani, G.; Franceschelli, M.; Musumeci, G.; Scodina, M. Geology of the Montigiu Nieddu metamorphic basement, NE Sardinia (Italy). J. Maps 2020, 16, 543-551. [CrossRef]

62. Cruciani, G.; Fancello, D.; Franceschelli, M.; Massonne, H.-J.; Langone, A.; Scodina, M. Geochemical and geochronological dataset of rutile from a Variscan metabasite in Sardinia, Italy. Data Brief 2020, 31, 105925. [CrossRef] [PubMed]

(C) 2020 by the authors. Licensee MDPI, Basel, Switzerland. This article is an open access article distributed under the terms and conditions of the Creative Commons Attribution (CC BY) license (http://creativecommons.org/licenses/by/4.0/). 